\title{
Market protection policy of the European Union against imports from China ${ }^{1}$
}

\section{Introduction}

China is currently the second largest trade partner of the European Union (after the United States), and the EU is China's most important trade partner. The EU trade with China accounts for almost $14 \%$ of all EU trade. China is the largest source of EU imports and its second largest export market. The value of the trade between the EU and China accounts on average for over EUR 1 billion a day. The EU imports mainly industrial and consumer goods, machinery and equipment, clothing and footwear from China. The main products exported from the European Union to China are: machinery and equipment, motor vehicles, airplanes and chemicals (the European Commission's data ${ }^{2}$ ).

The European Union is facing a growing imbalance in trade with China. In 2016, the trade deficit with China surpassed USD 260 billion (UN Comtrade ${ }^{3}$ ). Imports from China amounted to over USD 450 billion and the EU exports to China totaled less than USD 190 billion (UN Comtrade).

China's most important trade partners (the EU and US) treat this country in trade dealings as a non-market economy country, which is important in the implementation of anti-dumping procedures. Non-market economies are economies where the government has a full or almost total monopoly over trade exchange, and domestic prices are set by the state. Consequently, GATT 1994 and the Agreement on the Implementation of Article VI of the General Agreement of Trade and Tariffs allow considerable freedom in calculating the normal value of goods exported from a non-market economy for anti-dumping procedure purposes.

The aim of this article is to analyze the European Union's trade policy with regard to China in the context of the changes related to the expiry of China's transitional membership of the WTO in December 2016. The expiry of this transitional period has forced the European Union to change its policy regarding market protection. In particular, these changes concern anti-dumping proceedings. To achieve this, it has been assumed that granting or denying market economy status (MES) to China is a political decision that requires the European Commission to effectively balance the conflicting interests of EU member states while maintaining good relations with China. The sectors threatened by

1 This paper is part of the project under the grant entitled: Unia Europejska wobec przyspieszonego rozwoju Chińskiej Republiki Ludowej [The EU in the face of the accelerated development of the People's Republic of China], financed by NCN 2013/11/B/HS5/03572, OPUS 6.

${ }^{2} \mathrm{http} / / /$ ec.europa.eu/trade/policy/countries-and-regions/countries/china/.

${ }^{3} \mathrm{UN}$ Comtrade is a repository of official international trade statistics and relevant analytical tables, https://comtrade.un.org/. 
excessive Chinese imports, namely steel, chemical and metal industries, are important for some EU member states such as France, Italy and Poland. Therefore, any conflict over the market protection policy towards China constitutes a part of the overall problem of the future functioning and shape of the European Union. By extension, the division between the countries that are opposed to easing the EU policy towards Chinese imports and the countries that are willing to somehow revise it is clear. This division is mainly related to the importance of the threatened industries in the national economies of individual EU member states. The European Commission stands between these positions and it formally determines the shape of these changes. The paper argues that the aim of the European Commission is to dilute/blur the importance of market economy status in anti-dumping proceedings and replace it with another formula that will continue to provide protection for the EU's industry in sensitive sectors but will be less controversial for Chinese partners. The Chinese government is running an intensive campaign to be recognized as a market economy state (Kercrhoven, Luyten, 2014, p. 205). Thus, taking into account the conflicting interests of the involved parties, neither granting nor denying such status to China is in the interest of the European Union.

The literature on China's accession to the WTO and anti-dumping procedures is extensive. Some authors state that, according to China's WTO Accession Protocol, China should gain market economy status by the end of 2016 (e.g. Tietje, Nowrot, 2011; Rao, 2013). The next trend in the literature is based on the premise that the expiry of Section (15) (a) (ii) of China's WTO Accession Protocol does not mean that all WTO members would have to regard China as a market economy and that the problem lies in the interpretation of Article 15 (Puccio, 2015; Vermulst et al., 2016). On the other hand, however, some authors claim that this provision does not automatically require China to be granted market economy status by the end of 2016 (e.g. O'Connor, 2011, 2016; Miranda, 2014).

China's WTO Accession Protocol provides for a transitional period of 15 years to grant market economy status to China (Messerlin, 2004). However, it is debatable how to interpret Section 15 (D) of China's WTO Accession Protocol and whether or not it automatically grants market economy status to China after December 2016 (Puccio, 2015, p. 1). Furthermore, China is referred to as a non-market economy (NME) in China's WTO Accession Protocol. This means that China's economy is treated as centrally-controlled with a large government influence on prices, exchange rates and other aspects of the economy (Lou, 2010). A country recognized as a market economy should exhibit liquid exchange rates, free market and a clear definition of ownership and bankruptcy laws (Gajdos, Bendini, 2013). The absence of market economy status facilitates the application of anti-dumping procedures against China. It has a significant influence on determining the so-called normal price when calculating a magnitude of dumping (Snyder, 2010).

According to the authors of the frequently cited report from the Economic Policy Institute (EPI), a think-tank linked to US trade unions, granting market economy status to China poses a direct risk of losing between 1.7 million and 3.5 million jobs in the EU (Scott, Jiang, 2015). The key shortcoming of this report, as the analysts from the Centre for Eastern Studies point out, is that it does not take into consideration the historical trends in EU anti-dumping procedures against Chinese manufacturers dur- 
ing the last 15 years. In particular, losses in the industries listed by EPI as the most risky, such as clothing and textiles, furniture and electronics, with regard to which anti-dumping proceedings have been taking place only sporadically, seem to be overestimated (Jakubowski, Kaczmarski, 2015).

\section{Anti-dumping proceedings in the European Union}

Conditional favoritism measures, e.g. anti-dumping and anti-subsidy proceedings as well as procedures against excessive imports are now much more effective trade policy measures than the so-called classic instruments of trade policy, including primarily customs duties. The fact that China can still be treated as a non-market economy in anti-dumping investigations allows other WTO members to initiate antidumping investigations without a strict dumped-to-domestic price ratio in China. In practice, this means that the European Union compares the prices of Chinese goods sold on the European market with the prices of the same or similar goods on the markets of third countries with market economy status. This way of calculating whether or not dumping takes place makes it easier for the European Union to prove China's use of dumping prices.

The European Union generates $15 \%$ of global imports (the second largest result after the United States), while EU trade protection measures represent only $7.8 \%$ of such measures applied worldwide and concern only $0.21 \%$ of imported goods (COM(2016) 690). As regards the analysis of anti-dumping proceedings, 1,170 anti-dumping proceedings were initiated against China between 1995 and 2016, and 840 of them ended with the imposition of anti-dumping duties (WTO data). In this period, the European Union conducted a total of 485 anti-dumping proceedings, including 128 against China. The EU anti-dumping proceedings against China most often concerned metals and metal products -183 proceedings, chemical products -93 proceedings and machinery and mechanical devices - 53 proceedings (WTO data). The best-known trade disputes between the EU and China at the WTO forum were related to rare earth metals and solar panels. ${ }^{4}$

On the other hand, between 1995 and 2016, China conducted 231 anti-dumping proceedings, including 26 against EU manufacturers (WTO data). Over half of the Chinese proceedings concerned the chemical industry -122 proceedings.

The EU anti-dumping procedure is in line with the WTO rules in this regard. WTO members are also required to inform relevant WTO bodies of their domestic regulations and any amendments made thereto. Definitions of dumping are contained in Article VI of GATT/WTO under which dumping occurs when export goods are sold on the market below a normal price, i.e. a manufacturer's price. A relatively rare case of dumping is the sale of goods below their manufacturing cost, this is the so-called extreme example of dumping. The issue of the anti-dumping procedure is governed by Council Regulation (EC) No 1225/2009 which authorizes the imposition of antidumping duties when the following conditions are fulfilled simultaneously.

${ }^{4}$ For example, in the case of solar panels, the price at which they were exported from China was compared to the price in South Korea. In practice, the application of this analogue country method has given the EU the possibility of imposing higher customs duties on Chinese goods. 
First of all, applying a dumped price must generate injury or a threat to cause injury to a domestic industry, in this case the industry of the European Union. The causal link between injury and the occurrence of dumping should also be proved. This is quite important because the European Commission rarely takes action automatically on its own initiative, and most often it does so at the request of injured parties. The injury sustained by any industry must have an EU dimension and the companies requesting the initiation of the procedure must demonstrate at least $25 \%$ share in manufacturing a given product in the EU. Obviously, such a request may be submitted by a single company but also by associations thereof and companies from different EU countries. In addition, consumer interest in the European Union should be taken into account when making a decision.

The injury identified must be of significance for the EU industry manufacturing a similar product. Determining the extent of the injury requires examining the volume of imports and dumped prices and their impact on an EU industry. The Commission therefore examines whether there has been a significant increase in imports at dumped prices, both in terms of the volume of imported goods and in terms of their share on the European market. In order to determine the effect on prices, the extent to which the import price affects the price reduction of the EU manufacturers is an important factor. In order to determine the impact of dumping on the EU manufacturers such factors as market share, manufacture volume, profitability, efficiency, return on investment, ability to raise capital, magnitude of dumping, etc. are examined. It must be clearly demonstrated that given imports have caused injury to a domestic industry. This is usually the case when certain events coincide with each other: e.g. the intensification of imports and the decline in sales or manufacture volume of a domestic industry.

Granting market economy status to China in December 2016 would imply an obligation to calculate the so-called dumping margin when calculating an anti-dumping duty as per a normal price in the Chinese market, which in practice means treating imports from China in the same way as any other WTO member.

It is also worth noting that the WTO does not define market economy criteria. China's WTO Accession Protocol allows WTO members to assess, in accordance with their respective national laws, whether China has achieved market economy status or not. Thus, in the case of the EU trade policy, China is obliged to meet the EU criteria. The latter were set out in the Regulation of 27 April 1998 and then again in the Regulation of 30 November 2009 (Council Regulation No. 905/98). From the legal point of view the European Union has five criteria for granting market economy status. These are as follows: allocation of economic resources by the market, removal of barter exchanges, compliance with corporate governance, ownership rights and open financial sector, and liquid exchange rate (Vincentini, 2016). The issue of exchange rate is an important obstacle to granting market economy status to China. As long as China uses the artificial exchange rate of yuan for pro-export policy purposes, granting market economy status to the PRC will be debatable. This kind of currency manipulation helps Chinese exports be more competitive versus American or European products.

Current EU regulations set a maximum limit on the level of anti-dumping duties, which is being criticized by some EU member states. This is caused by the use of the so-called lesser duty rule. It means that anti-dumping duties are imposed at the level 
of the dumping margin or at a level which allows for the removal of injury, whichever is lower ("lesser duty"). The dispute regarding the lesser duty effectively blocked the reform of EU market protection measures proposed by the EC in 2013 for over three years. Scandinavian countries, the Netherlands and Great Britain, which were more liberally-orientated to the trade with China, were against the abolition of this rule. The lesser duty rule effectively prevented the EU from imposing high anti-dumping duties. For example, in the anti-dumping case regarding hot-rolled coils, the dumping margin was $102 \%$ and the injury margin was $19 \%$, and it was ultimately imposed on the basis of the lesser duty rule. In practice this means that for the comparable imports at dumped prices and originating from China, such as some flat cold rolled steel products, the EU average anti-dumping duty was $21.1 \%$, whereas in the case of the USA, the average anti-dumping duty amounted to $265.8 \%$ in 2015 (COM(2016) 690). It is worth emphasizing that the EU lesser duty rules go beyond the framework set by the WTO Anti-Dumping Agreement and that the vast majority of WTO members (including the USA) do not benefit from this type of solution.

\section{Divergent interests of the $\mathbf{E} U$ member states}

The European Commission is responsible for granting market economy status to China once it has consulted with the European Parliament. Consequently, the European Commission is responsible for working out a compromise between frequently mutually exclusive positions, on one hand - the European manufacturers' lobby protesting against granting market economy status to China, on the other hand - varied interests of the EU member states, and China's position. A challenge within the EU is also the cooperation with the European Parliament, which in May 2016 unequivocally opposed granting market economy status to China by the end of 2016 (majority 546 to 28).

The debate on granting market economy status to China is another issue that has divided EU member states. This division is roughly the same as in the financial crisis where the "North" supports granting this status in 2016 and the "South" is clearly against. Germany stands in the middle. The opinion of new member states, such as Poland and other Central and Eastern European countries, is not clear. Great Britain, the Netherlands and Scandinavian countries support China's efforts to be granted market economy status, and in 2014 they successfully blocked the EC proposal on the reform of market protection instruments. Their position, however, was weakened by the outcome of the United Kingdom European Union membership referendum in June 2016. Germany, in turn, allows China to be granted this status but, at the same time, it is interested in providing additional security to sensitive industries. Italy, Spain and France strongly opposed granting market economy status to China automatically in December 2016 (Wnukowski, 2016).

Alongside the textile and ceramics manufacturers, the steel industry is most involved in lobbying for denying market economy status to China. It is represented by Eurofer - the European Steel Association which is active in the media and is lobbying in the European Parliament and the European Commission against China. The European steel industry is the world leader with a turnover of about EUR 170 billion and 
headcount of approximately 330,000 highly skilled workers, producing an average of 170 million tonnes of steel a year. ${ }^{5}$ Eurofer's experts claim that granting market economy status to China will mean that European manufacturers will have to work under "constant price pressure" and excessive imports of Chinese steel has already caused prices to fall by ca. $40 \%$ in comparison with $2013(\mathrm{COM}(2016))$. EU steelmakers also point out that Chinese manufacturers use government export subsidies to boost their competitiveness on foreign markets.

European steel associations also argue that China's steel production may soon reach 400 million tonnes - nearly double the European production. China has also announced an increase in employment in industry from around five to six million jobs in the next three years, of which 1.8 million are in the steel and mining industries. Eurofer argues that the opening of the European market to Chinese steel obviously jeopardizes 330,000 European jobs in this sector. AEGIS Europe - the organization of 30 European manufacturers' associations from various industries, including traditional industries, consumers, SMEs and the renewable energy sector is also protesting granting market economy status to China. ${ }^{6}$

When debating the change of methodology for calculating dumping margins in antidumping proceedings against China and adjusting EU trade protection instruments to a new economic and legal reality, the European Commission took into account three scenarios: (1) leaving EU rules unchanged, (2) removing China from the list of countries with non-market economy and using the standard methodology for calculating dumping margins, and (3) replacing the anti-dumping method with a new approach that would maintain a strong trade protection system while, at the same, time ensuring the effectiveness of the EU international commitments. The proposal of new solutions for the EU market protection and calculating a dumping margin set out in July 2016 by the European Commission was in line with scenario 3 above. The European Commission proposed a common methodology for calculating a dumping margin for all WTO members, which in practice meant eliminating the division between the countries with and without market economy status. As a result, the EC proposed a new method for calculating dumping margins for imports from countries with market distortions or where the state has a dominant impact on the economy. The new arrangements also provide for a transitional period in which anti-dumping measures and anti-dumping proceedings applied so far will remain in force until their expiry (COM (2016) 690 final). In May 2017, the EC proposal was welcomed by the EU member states. ${ }^{7}$ Any further procedure, however, requires the final text of the agreement to be agreed with the European Parliament.

\section{Conclusion}

The interests of China and the European Union with regard to trade policy are contradictory. However, the European Commission is aware that any aggravation of

${ }^{5} \mathrm{http}: / /$ www.eurofer.org/About\%20us/Eurofer\%20Portrait.fhtml.

${ }^{6} \mathrm{http}: / / \mathrm{www} \cdot$ aegiseurope.eu/about/.

7 Anti-dumping methodology: Council agrees negotiating position, PRESS RELEASE 231/1703/05/2017, http://www.consilium.europa.eu/press-releases-pdf/2017/5/47244658414_en.pdf. 
the trade relations with China in terms of trade protection measures can have a negative impact on all economic relations between the European Union and the PRC. On the other hand, by removing the possibility of proving dumping without much trouble and thereby protecting the EU market, the European Union is exposed to the threat of job losses and deeper recession in the sectors that are unable to compete with low-cost Chinese imports. These are traditional sectors, such as steel and textiles industries, whose representatives are active in campaigning against granting market economy status to China. They argue that cheap imports of steel from China are destroying the European economy, and without the possibility of imposing anti-dumping duties, the future of this industry in the EU is threatened. Thirdly, the EU member states are polarized when it comes to granting market economy status to China. Great Britain and the Netherlands are willing to accept Chinese demands, while other countries such as Italy and France are strongly opposed. In addition, in May 2016 the European Parliament voted against granting market economy status to China and adopted a non-binding resolution calling on the European Commission to take into account the concerns of the EU industries, trade unions and stakeholders with respect to the possible consequences of granting this status to China for the labor market, environmental protection and economic growth in the EU. Accordingly, it seems that the European Commission's proposal to give up the division of countries into ones with or without market economy status while retaining the possibility to penalize manufacturers who use dumping is good. Granting market economy status to China also has a symbolic effect for China as a confirmation of its equal trade status and the completion of the WTO accession process.

\section{Bibliography}

Agreement on Implementation of Article VI of the General Agreement on Tariffs and Trade 1994), https://www.wto.org/english/docs_e/legal_e/19-adp_01_e.htm.

Agrement on implementation of Article VI of the General Agreement on Tariffs and Trade 1994 (1999), in: The Legal Texts. The results of the Uruguay Round of Multilateral Trade Negotiations, WTO, Cambridge University Press.

Council Regulation No 1225/2009 of 30 November 2009 on protection against dumped imports from countries not members of the European Community, Official Journal of the European Union L 343/51.

Council Regulation No 905/98 of the Council of 27th April 1998 leading to the modification of regulation (CE) no. 384/96, http://eur-lex.europa.eu/legalcontent/EN/TXT/PDF/?uri=CELEX:31 998R0905\& from $=\mathrm{EN}$.

Gajdos L. Bendini R. (2013), Trade and economic relations with China, Policy Briefing, DG EXPO/B/ PolDep/Note/2013_123.

Gertler J. L. (2004), What China's WTO accession is all about, in: China and the WTO, Accession, Policy reform, and poverty reduction strategies, eds. D. Bhattasali, S. Li, W. Martin, World Bank and Oxford, University Press.

Guijn L., Bi T. (2015), China's role In the WTO: Opening up as a way to push forward reforms and combat trade protectionism in China's WTO Accession Reassessed, Luolin W. (Editor), Routledge Studies on the Chinese Economy. 
Jakubowski J., Kaczmarski M. (2016), UE wobec statusu gospodarki wolnorynkowej dla Chin: kompromis czy unik?, Komentarze OSW no. 221.

Kercrhoven van S., Luyten A. (2014), The tale of a Trojan horse or the quest for market access? China and the World Trade Organization, Rev. Bras. Polit. int. 57 (special edition).

Luo Y. (2010), Anti-dumping in the WTO, the EU and China. The Rise of Legalization in the Trade Regime and its Consequences, Kluwer Law International.

Miranda J. (2014), Interpreting Paragraph 15 of China's Protocol of Accession, Global Trade and Customs Journal 19.

Messerlin P. A. (2004), China in the WTO: Antidumping and safeguards, in: China and the WTO, Accession, Policy reform, and poverty reduction strategies, eds. D. Bhattasali, S. Li, W. Martin, World Bank and Oxford, University Press.

O'Connor B. (2016), Much Ado about 'Nothing': 2016, China and Market Economy Status, "Global Trade and Customs Journal", vol. 10, no. 5.

O'Connor B. (2011), Market Economy Status for China is not Automatic, CEPR's Policy Portal, http://voxeu.org/article/china-market-economy, 10.03.2016.

Puccio L. (2015), Granting of Market Economy Status to China. An analysis of WTO law and of selected WTO members ' policy, European Parliamentary Research Service, November 2015/ PE571.325.

Scott R., Jiang X. (2015), Unilateral grant of Market Economy Status to China would put millions of EU jobs at risk, Economic Policy Institute, EPI Briefing Paper 407.

Snyder F. (2010), The EU, the WTO and China. Legal Pluralism and International Regulation, Hart, Oxford-Portland.

Tietje Ch., Nowrot K. (2011), Myth or reality? China's Market Economy Status under WTO AntiDumping Law after 2016, Policy Papers on Transnational Economic Law, no. 34.

Towards a robust trade policy for the EU in the interest of jobs and growth, Brussels, 18.10.2016 $\operatorname{COM}(2016) 690$ final, https://ec.europa.eu/transparency/regdoc/rep/1/2016/EN/1-2016-690EN-F1-1.PDF.

Vermulst E., Dion Sud J., Evenett S. J. (2016), Normal value in anti-dumping proceedings against China post-2016: Are some animals less equal than others?, "Global Trade and Customs Journal", vol. 11, no. 5.

Vincentini D. (2016), MEPs braced for fight over granting China 'Market Economy'status, http:// www.euractiv.com/section/trade-society/news/meps-braced-for-fight-over-granting-chinamarket-economy-status/.

Wnukowski D. (2016), Kwestia przyznania ChRL statusu gospodarki rynkowej-implikacje dla UE i Polski, „Biuletyn PISM”, nr 54.

WTO data, Statistics on anti-dumping, https://www.wto.org/english/tratop_e/adp_e/adp_e.htm.

\section{Summary}

The aim of this paper is to analyze the European Union's trade policy with regard to China in the context of the changes related to the expiry of the transitional period of China's membership of the WTO in December 2016. The expiry of this transitional period necessitates certain changes in anti-dumping proceedings of the European Union. In order to achieve the purpose of the paper it has been assumed that granting or denying market economy status to China is primarily a political decision which requires taking into account contradictory interests of the EU member states.

Key words: European Union, China, dumping, trade policy 


\section{Polityka ochrony rynku Unii Europejskiej wobec importu z Chin ${ }^{8}$}

\section{Streszczenie}

Celem artykułu jest analiza polityki handlowej Unii Europejskiej wobec Chin w kontekście zmian jakie są związane z wygaśnięciem okresu przejściowego członkostwa Chin w WTO, które nastąpiło w grudniu 2016 roku. Wygaśnięcie owego okresu przejściowego wymusza na Unii Europejskiej pewne zamiany zwłaszcza w postępowaniach antydumpingowych. Dla zrealizowania celu pracy przyjęto że przyznanie lub nie statusu gospodarki rynkowej Chinom jest przede wszystkim decyzją polityczną wymagającą uwzględniani sprzecznych interesów państw członkowskich UE.

Słowa kluczowe: Unia Europejska, Chiny, dumping, polityka handlowa

${ }^{8}$ Artykuł jest częścią projektu w ramach grantu Unia Europejska wobec przyspieszonego rozwoju Chińskiej Republiki Ludowej, finansowanego z NCN 2013/11/B/HS5/03572, OPUS 6. 
